\title{
CT-Guided Percutaneous Cordotomy for Intractable Pain in What is More than a Disease: Lung Malignancies
}

\author{
Akciğer Malignitelerinde İnatç Ağrular İçin BT - Rebberliğinde Perkütan \\ Kordotomi
}

\author{
Yucel KANPOLAT ${ }^{1}$, Mevci OZDEMIR ${ }^{2}$, Eyyub S. M. AL-BEYATI ${ }^{3}$ \\ ${ }^{1}$ President of the Turkish Academy of Sciences, Emeritus, Ankara University, Faculty of Medicine, Department of Neurosurgery, Ankara, Turkey \\ ${ }^{2}$ Pamukkale University, Faculty of Medicine, Department of Neurosurgery, Denizli, Turkey \\ ${ }^{3}$ Graduate of Ankara University, Faculty of Medicine, Ankara, Turkey
}

Correspondence address: Yucel KANPOLAT / E-mail: kanpolat@ada.net.tr

\begin{abstract}
AIM: Lung cancer is the leading cause of cancer-related mortality worldwide. Pain is a common problem in these patients, yet inadequate or dissatisfactory management is prevalent.

MATERIAL and METHODS: Between 1987 and 2012, 224 patients with intractable pain were treated with computerized tomography (CT)guided cordotomy. Among them, 210 had intractable pain due to malignancies. The majority of the cases were diagnosed as pulmonary malignancies (108 patients). Sixty-seven were pulmonary carcinoma, 26 mesothelioma and 15 Pancoast tumors.

RESULTS: After cordotomy, $98.13 \%$ of cancer patients reported initial pain relief. Minimum and maximum preoperative scores of the Karnofsky Performance Scale were 20 and 70, versus postoperative scores of 40 and $90(p<0.001)$. The median preoperative VAS score was $8(6-9)$. On the first postoperative day, the score dropped sharply to $0(0-8)(p<0.001)$. In this selected series of 108 percutaneous cordotomy procedures, as well as in the total series of 224 patients, there was no mortality or major morbidity.

CONCLUSION: CT-guided percutaneous cordotomy is an effective procedure that should be used in the treatment of cancer-related pain problems. We suggest that cordotomy should be preferred as soon as possible in patients who fail to respond to the classic analgesic therapy. KEYWORDS: Pulmonary carcinoma, Mesothelioma, Pain
\end{abstract}

\section{Öz}

AMAÇ: Akciğer kanseri dünyada kansere bağlı ölüm nedenlerinin başında gelmektedir. Ağrı, bu hastalarda yaygın bir problem olmasına rağmen yetersiz veya tatmin etmeyen ağrı yönetimi yaygındır.

YÖNTEM ve GEREÇLER: 1987-2012 yılları arasında, inatçı ağrısı olan 224 hasta bilgisayarlı tomografi (BT) rehberliğinde perkütan kordotomi yöntemiyle tedavi edildi. Bunların arasında, 210'unun inatçı ağrısı maligniteye bağlı idi. Vakaların büyük çoğunluğu pulmoner malignite (108 hasta), 67'si pulmoner karsinoma, 26'sı mezotelyoma ve 15'i Pancoast tümörü tanısı almışlardı.

BULGULAR: Kordotomi uygulaması sonrasında kanser hastalarının \% 98,13'ü ağrılarının başlangıçta geçtiğini bildirdiler. Karnofsky Performans Skalası skorlarının preoperatif minimum ve maksimum değerleri 20-70 iken, postoperatif değerler $40-90$ idi $(p<0,001)$. Preoperatif VAS skoru ortanca değeri 8 (6-9) idi. Postoperatif ilk günde bu skor bariz olarak 0 (0-8)'a düşmüştür ( $<<0,001)$. Toplam 224'lük seride olduğu gibi, seçilen 108 hastanın olduğu perkütan kordotomi serisinde de mortalite veya major morbidite yoktur.

SONUÇ: BT rehberliğinde perkütan kordotomi etkili bir yöntem olup kansere bağı inatçı ağrıların tedavisinde kullanılması gereklidir. Önerimiz, kordotominin, klasik analjezik terapilere yanıt vermeyen hastalarda zaman kaybedilmeden tercih edilmesi ve kullanılması yönündedir.

ANAHTAR SÖZCÜKLER: Akciğer Kanseri, Mezotelyoma, Ağrı

\section{INTRODUCTION}

Cancer and cancer-related disorders remain significant public health problems. Cancer incidence continues to be on the rise due to the increase in the average lifespan, growth of the population and changing environmental conditions worldwide. Despite the unquestioned benefits of economic development and the rapid advances in technology, as they concern health, their invasion into nearly every aspect of our daily lives is reflected negatively in our sedentary lifestyle, unhealthy nutritional habits and exposure to air pollution, all of which may be cancer-causing factors.

Lung cancer is the leading cause of cancer-related mortality worldwide (16). Approximately 1.6 million new lung cancer cases are diagnosed in the world each year, about 220,000 of 
which are diagnosed in the United States $(1,17)$. The lung is the leading cancer site in males, comprising $17 \%$ of the total new cancer cases and $23 \%$ of the total cancer deaths (15).

Early detection is the major goal, but only $15 \%$ of lung cancer is diagnosed in the early stage. The 5-year survival rate for all stages combined is only $16 \%$ (1). Substantial numbers of patients diagnosed with localized disease are often unsuitable for curative surgical procedures due to concomitant medical illness (32). The prognosis remains unsatisfactory, and the development of new therapeutic strategies is still an urgent demand (2).

Serious problems like pain, fatigue, insomnia, and mood disturbance due to cancer or to the treatment itself increase the burden of the case and further complicate management of the disease. The available literature underlines the fact that these four symptoms may occur in a cluster and negatively influence a patient's life quality during cancer therapy; thus, there is a need to evaluate effective interventions to solve them $(5,34)$.

Studies confirm that adults with lung cancer have more symptoms than patients with other types of cancer (8). Pain is a common problem in these patients, such that approximately $75 \%$ of those with advanced stage cancer experience pain, yet inadequate or dissatisfactory management is prevalent $(12,24)$. Despite the high prevalence of cancer-related pain and the associated disability, it is frequently undertreated $(4,6,7,10,30,35)$.

Pain may be caused by the progression of the tumor or the treatment itself, including surgery, chemotherapy and radiation. Pain may cause decreased activity, anorexia and sleep deprivation, all of which weaken patients in their fight against cancer.

This paper was prepared with the aim of stressing that pain management in cancer patients, especially those with lung cancer, is as important as the cancer treatment itself. Although developing technologies, cordotomy technique is still not widely used for control of cancer pain all over the world (33). Appropriate pain management can provide an acceptable quality of life for the patient and facilitate compliance with the primary treatment.

\section{PATIENTS and METHODS}

Between 1987 and 2012, 224 patients with intractable pain were treated by only one surgeon by computerized tomography (CT)-guided cordotomy in the Department of Neurosurgery, Ankara University and in the private practice of the senior author. Among the 224 patients in the series, 210 had intractable pain due to malignancies. The majority of the cases were diagnosed as pulmonary malignancies (108 patients). Of the 108 admitted for treatment of intractable pain, 67 were pulmonary carcinoma, 26 mesothelioma and 15 Pancoast tumors.

Cordotomy is based on the lesioning of the lateral spinothalamic tract in the anterolateral spinal cord, which transmits the pain sensation (Figure 1). The procedure is preferred especially in nociceptive intractable pain problems in malignancy (21). Since 1987, cordotomy has been performed using special needle electrodes with the help of CT imaging (19). Most intractable pain in cancer patients is nociceptive at the onset, caused by nerve irritation. Over time, the nociceptive pain progresses to neuropathic pain due to neural damage, and this type of pain is continuous. As defined by the patients, the sensations are burning and throbbing (36).

A visual analogue scale (VAS) was used to score the severity of the pain, and the Karnofsky performance scale was used to determine the performance status of the patients on the first postoperative day. Post-cordotomy, the pain measurement scale was determined as follows: I - no pain, II - partial satisfactory pain relief, III - partial non-satisfactory pain relief, and IV - no change in pain. In this grading system, grade I and II patients were considered as having pain relief and grade III and IV considered as failing in obtaining the desired pain relief after surgical intervention.

The Wilcoxon signed rank test was used to test the differences between pre- and postoperative VAS and Karnofsky Performance Scale scores. SPSS for Windows (Version 17.0; SPSS, Inc.) was used for statistical analysis. A P value of less than 0.05 was considered significant.

\section{CT-GUIDED PERCUTANEOUS CORDOTOMY TECHNIQUE}

The target in cordotomy is the lateral spinothalamic tract located in the anterolateral part of the spinal cord $(14,40)$. This ascending tract carries information chiefly about pain and temperature and relays some tactile information (Figure 1). The organization of fibers from the outside inward reflects superficial pain, temperature and deep pain, respectively (36). Because most fibers in the anterolateral system decussate over two to five segments before entering the anterolateral columns, spinothalamic cordotomy aims to interrupt the spinothalamic tract ascending contralaterally to the painful side (40).

The anterolateral sensory system has a somatotopic relationship, with fibers from higher levels laminating medially and ventrally and fibers from lower levels laminating laterally and dorsally within the lateral spinothalamic tract $(14,36)$. Segmentation of the fibers provides the opportunity for selective cordotomy, given that anteromedial lesions denervate the contralateral arm and upper chest region, while posterolateral lesions denervate the sacral and lumbar areas (Figure 1) (21).

The percutaneous cordotomy operation is principally based on the lesioning of the lateral spinothalamic tract, which carries pain and temperature sensations, at the C1-C2 level (Figures $2 A, B, 3,4 A, B)$. The procedure is performed contralaterally to the pain side. The best candidates are those with unilateral localized intractable nociceptive-type somatic cancer pain, as seen in mesothelioma of the chest wall or malignancy of the lower extremities and those with unilateral localized pain 


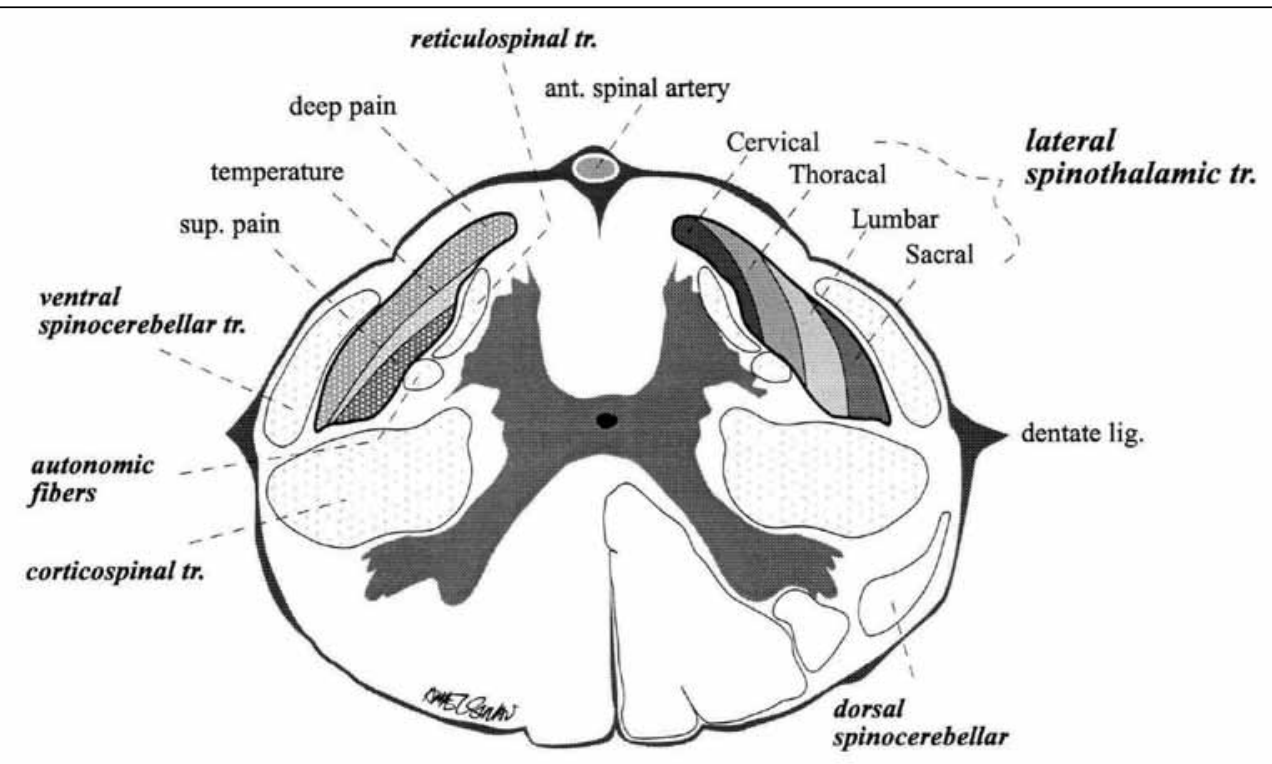

Figure 1: Schematic representation of target (lateral spinothalamic tract) and its environs at the C1-C2 level.

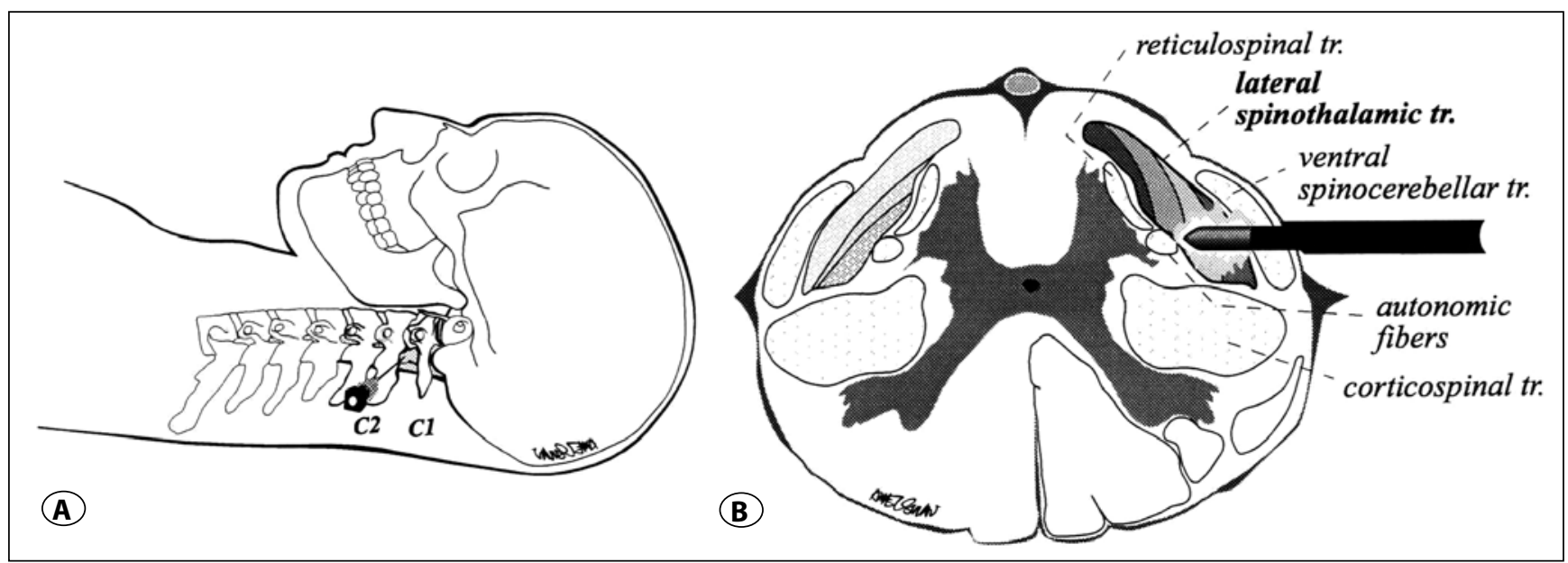

Figure 2: Schematic representation of lateral percutaneous cordotomy at the C1-C2 level. A) Position of the needle at the C1-2 level. B) Ideal positon of the needle electrode system in the target.

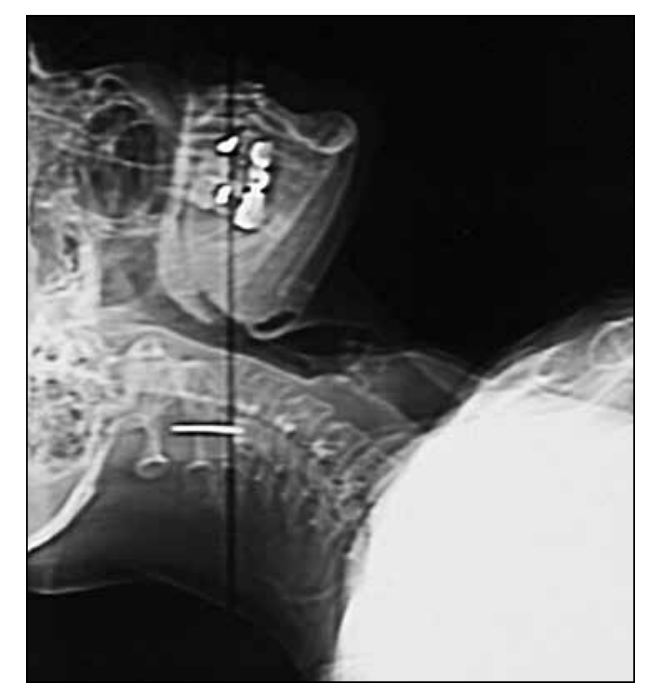

Figure 3: Final position of the needle at the $\mathrm{C} 1-2$ level on lateral scanogram. problems $(18,20)$. Secondary candidates are patients with nociceptive pain at the onset of the disease, but in whom the pain may evolve to neuropathic form if the tumor infiltrates the brachial plexus, as in Pancoast tumors. These patients are accepted as candidates for cordotomy. Patients suffering from pure neuropathic pain were not considered as candidates for cordotomy in our series because the procedure is not effective in neuropathic pain (20).

An important point that needs to be stressed is that in some cases of Pancoast tumors, the problem starts as nociceptive pain. Later, the clinical picture turns to the infiltration of the plexus and causes neuropathic pain. This situation must be explained to the patient. Patients with severe pulmonary dysfunction in whom partial oxygen saturation is lower than $80 \%$ are also not suitable candidates for cordotomy. If heavy pleural effusion is present, we suggest its drainage preoperatively, but if it persists, it is recommended to 


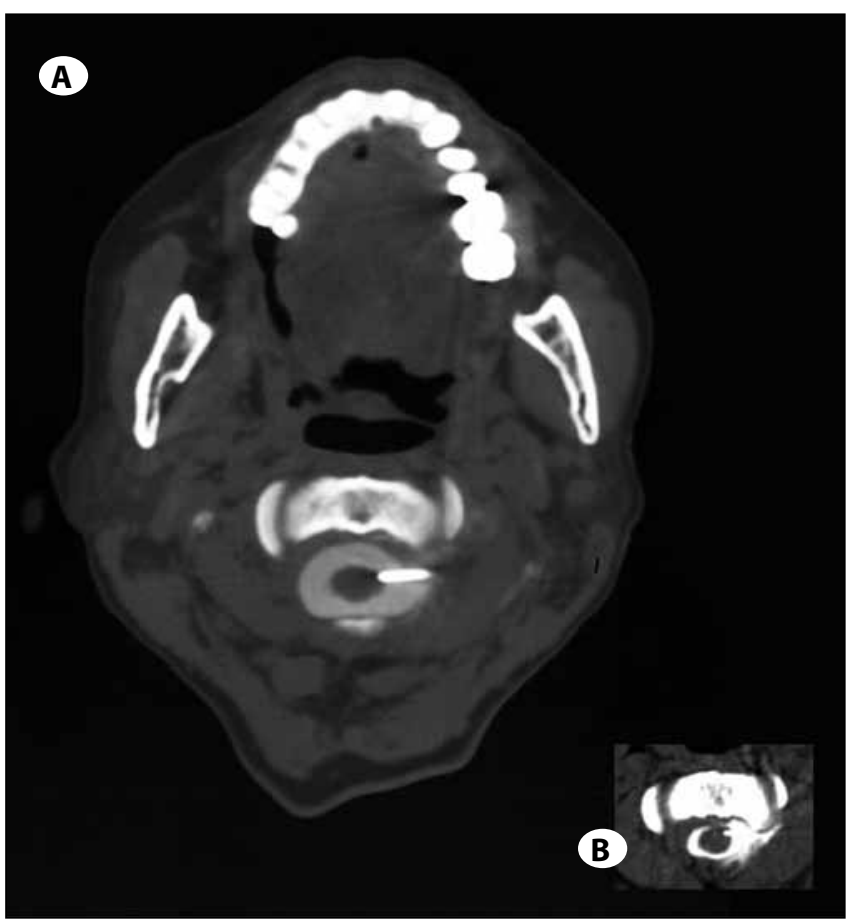

Figure 4: A) Position of the needle in the target at the C1-2 level with anteroposterior projection. B) Final position of the electrode in the target.

delay the procedure and consult with the Department of Pulmonary Diseases. The cordotomy procedure should be considered carefully if the patient is receiving chemotherapy or radiotherapy for cancer. Detailed information about the procedure and the expectations from the procedure should be clearly explained to both the patient and family (20).

\section{RESULTS}

Between 1987 and 2012, a special segment of cancer patients with lung cancer were treated with CT-guided percutaneous cordotomy. This group is the largest cancer patient group in our practice. Intractable pain due to lung cancer was treated in 108 patients from 1987-2012 without any mortality or important morbidity.

Table I: Median (Minimum-Maximum) Karnofsky Performance Scale (KPS) and Visual Analog Scale Scores (VAS)

\begin{tabular}{|c|c|c|c|}
\multirow{2}{*}{} & \multicolumn{3}{|c|}{ Total } \\
\cline { 2 - 4 } VAS & Preop. & Postop. & P \\
\hline KPS & $8(6-9)$ & $0(0-8)$ & $<0.001$ \\
\hline
\end{tabular}

The series included 85 males (78.7\%) and 23 females (21.3\%), with a mean age of $53.8( \pm 10.4)$ years. The majority of cases were attributable to pulmonary carcinoma $(n=67)$, followed by mesothelioma $(n=26)$ and Pancoast tumors $(n=15)$.

After cordotomy, $98.13 \%$ of patients reported pain relief (Grade I, 88.88\%; Grade II, 9.25\%; Grade III, 1.85\%; Grade IV, 0.0\%). The median preoperative VAS score was 8 (6-9). On the first postoperative day, the score dropped sharply to $0(0-8)(p<0.001)$. The Karnofsky Performance Scale was used immediately pre- and postoperatively as a measure of change in patient performance. Minimum and maximum preoperative scores were 20 and 70 , versus postoperative scores of 40 and 90 , and the difference was determined to be highly significant $(p<0.001)$. Median (minimum - maximum) Karnofsky Performance Scale and VAS scores of the cordotomy procedures in total are summarized in Table I.

The results of cordotomy procedures divided according to the specific lung cancer types are summarized in Table II. The differences in each group pre- and postoperatively were determined to be highly significant $(p \leq 0.001)$.

Complications were prevented by avoiding incorrect localization with direct imaging guidance with CT scanning and by avoiding creation of large lesions by using thinner electrodes, e.g., the Kanpolat Computed Tomography Electrode.

In this selected series of 108 percutaneous cordotomy procedures, as well as in the total series of 224 patients, there was no mortality or major morbidity $(20,21,22,23)$. Dysesthesia was seen in 4 patients $(1.78 \%$, one with Pulmonary Carcinoma, one with Pancoast tumor, one with mesothelioma and the other with Malignant Melanoma) and accepted as a real complication after the procedure. Motor weakness was seen in one patient but considered as a transient complication and disappeared within about 2 weeks postoperatively.

\section{DISCUSSION}

Lung cancer and especially the pain it causes are socialhumanitarian problems in addition to their burden as healthcare problems. The International Association for the Study of Pain (IASP) has recognized pain relief as a human right (3). Patients with cancer differ from others in their necessity for a better life quality and for prevention, to the extent possible, of the associated symptoms that may develop as a result of the primary treatment. Pain, fatigue, insomnia, anorexia, and constipation are among the primary and most frequent of the many problems occurring secondary to cancer and its treatment, and they must be managed appropriately (5).

Table II: Median (Minimum - Maximum) Karnofsky Performance Scale (KPS) and Visual Analog Scale Scores (VAS)

\begin{tabular}{|c|c|c|c|c|c|c|c|c|c|}
\hline & \multicolumn{3}{|c|}{ Pulmonary Ca } & \multicolumn{3}{|c|}{ Mesothelıoma } & \multicolumn{3}{|c|}{ Pancoast } \\
\hline & Preop. & Postop. & $\mathbf{P}$ & Preop. & Postop. & $\mathbf{P}$ & Preop. & Postop. & $\mathbf{P}$ \\
\hline VAS & $8(6-9)$ & $0(0-5)$ & $<0.001$ & $8(7-9)$ & $0(0-8)$ & $<0.001$ & $8(7-9)$ & $1(0-3)$ & 0.001 \\
\hline KPS & $50(20-70)$ & $70(20-70)$ & $<0.001$ & $40(20-60)$ & $70(50-90)$ & $<0.001$ & $40(20-70)$ & $70(50-80)$ & 0.001 \\
\hline
\end{tabular}


The American Pain Society calls attention to the five important areas in the management of pain. It is recommended: to recognize and treat pain promptly; involve the patients and families in the pain-management plan; improve treatment patterns by eliminating inappropriate practices and providing multimodal therapy; and reassess and adjust the pain management plan as needed (28).

In this science and technology age in which we live, the following question is worth considering: 'What solutions can we offer oncological patients for their pain problems?' If science cannot provide even a painless death, this is a serious problem requiring immediate attention. The question to ask is whether to wait till the terminal stage to do something for pain or not. It is extremely important to consider persistent pain as a humanity problem beside being a health problem.

There is no doubt that an effective means of pain management in cancer patients is needed immediately. This is a social necessity. Some of our patients, with their primary disease under control, were able to return to their normal active life immediately after the cordotomy procedure.

The long-term follow-up of the patients in our series is inadequate. Nevertheless, the current results and outcomes of the procedure indicate that cordotomy is effective for intractable lung cancer pain, especially in mesothelioma (22).

Pain management practice needs to be basic but also effective. Making the patient dependent on physicians or the healthcare system is a cause of disability in the conduct of daily life (18). The patient's confidence regarding the method of pain treatment is very important for its success and over the disease course. The literature emphasizes that patients are reluctant to report their pain as a side effect, for fear of distracting the physicians from treating the cancer and due to their belief that pain is indicative of progressive disease $(11,27,29,31,37,38,39)$.

Some of our patients and their relatives have suggested that the cordotomy procedure be implemented worldwide and that physicians be encouraged in its use. We believe and suggest that cordotomy is the best solution for intractable pain problems in some patients suffering from lung cancer. This is the art of choosing the best procedure for the patient. We suggest that patients should be examined and followed by the same expert. Changing the physician over the treatment course will negatively affect the success of the process.

Opioid agents are primarily used to provide analgesia in cancer patients. However, they may be inadequate for pain palliation, or the therapy may be stopped because of the severe side effects or due to misuse. In Denmark, where opioids are prescribed liberally for chronic pain, Eriksen et al. reported worse pain, higher healthcare utilization and lower activity levels in opioid-treated patients compared to a matched cohort study of chronic pain patients not using opioids, suggesting that when opioids are prescribed liberally, even if some patients benefit, the overall population does not $(9,25)$.
In addition to the observed side effects of opioids like constipation and nausea, against which no tolerance develops, physical dependence, tolerance, breath depression, hyperalgesia, and immunologic dysfunction may occur. Recent studies have shown that neural plasticity associated with the development of opioid tolerance may activate a pronociceptive mechanism that could counteract the analgesic effects of opioids (26).

Gybels suggests that selected patients for the classic cordotomy procedure should be assumed to have at least 2-5 months of survival (13). However, according to our series and the result of procedures in approximately 250 patients, unless the patient is in agony, we believe that cordotomy is effective and has to be chosen in all cancer patients even if they have only a few weeks of survival.

In general, physicians and the relatives of cancer patients are afraid of applying invasive risky procedures in terminally ill patients. Contrary to this approach, and also according to the feedback of our patients, CT-guided percutaneous cordotomy should be considered as a good option. Most of the patients in our series insisted on having the procedure applied, whatever the risks. It is important to ask "why?". Cancer patients suffering from pain dream of being able to sleep more than one hour continuously per day, eat whatever they want, return to an active life, and socialize with their friends, etc.

The cancer patient has more than just the cancer disease! It is crucial to recognize this reality and to provide whatever is needed for these short-survival cases. Molecular and other studies are important and may be promising for the improvement of survival in cancer cases, but these are meaningless for the patient if other necessities are forgotten.

CT-guided percutaneous cordotomy is an effective procedure that should be used in the treatment of cancer-related pain problems. The safety of the procedure depends on correct patient selection and the experience of the surgeon. We suggest that cordotomy should be preferred as soon as possible in patients who fail to respond to the classic analgesic therapy.

\section{ACKNOWLEDGEMENT}

We express our gratitude to Atilla Halil Elhan (PhD, Professor. Department of Biostatistics, Ankara University, Faculty of Medicine) for carrying out the statistical analysis; Ahmet Sinav (MD, Professor, Department of Anatomy, Trakya University, School of Medicine, Edirne, Turkey) for his creative drawings; Mrs. Mukaddes Kurum Yucel for her assistance in writing the manuscript and Mrs. Corinne Logue Can for her language editing.

The figures 1 and 2 were used in the article published in the Youmans Neurological Surgery, 5th Ed., Vol. 3, H. Richard Winn, Yücel Kanpolat, Cordotomy for Pain, pp. 3060-3063, Copyright Elsevier, Saunders, 2004.

This work was partly supported by the Turkish Academy of Sciences (TÜBA). 


\section{REFERENCES}

1. American Cancer Society: Cancer Facts and Figures 2010. Atlanta: American Cancer Society, 2010

2. Bishay A, Raoof S, Esan A, Sung A, Wali S, Lee LY, George L, Saleh A, Baumann M: Update on pleural diseases--2007. Ann Thorac Med 2: 128-42, 2007

3. Brennan F, Cousins M: International Association for the Study of Pain. Pain relief as a human right. Pain Clin Updates 12(5): 1-4, 2004

4. Carr D, Goudas L, Lawrence D, Pirl W, Lau J, DeVine D, Kupelnick B, Miller K: Management of Cancer Symptoms: Pain, Depression, and Fatigue. Rockville, MD: Agency for Healthcare Research and Quality. Evidence Report/ Technology Assessment 61: 2-32, 2002

5. Cheng KK, Lee DT: Effects of pain, fatigue, insomnia, and mood disturbance on functional status and quality of life of elderly patients with cancer. Crit Rev Oncol Hematol 78: 127-137, 2011

6. Cleeland $\mathrm{CS}$, Gonin $\mathrm{R}$, Hatfield $\mathrm{AK}$, Edmonson $\mathrm{JH}$, Blum $\mathrm{RH}$, Stewart JA, Pandya KJ: Pain and its treatment in outpatients with metastatic cancer. N Engl J Med 330: 592-596, 1994

7. Cleeland CS: Undertreatment of cancer pain in elderly patients. JAMA 279: 1914-1915, 1998

8. Cooley ME: Symptoms in adults with lung cancer: A systematic research review. J Pain Symptom Manage 19: 137-153, 2000

9. Eriksen J, Sjøgren P, Bruera E, Ekholm O, Rasmussen NK: Critical issues on opioids in chronic non-cancer pain. An epidemiological study. Pain 125: 172-179, 2006

10. Fallowfield L, Radcliffe D, Jenkins V, Saul J: Psychiatric morbidity and its recognition by doctors in patients with cancer. Br J Cancer 84: 1011-1015, 2001

11. Ferrell BR, Grant M, Ritchey KJ, Ropchan R, Rivera LM:The pain resource nurse training program: $A$ unique approach to pain management. J Pain Symptom Manage 8: 549-556, 1993

12. Gordon DB, Dahl JL, Miaskowski C, McCarberg B, Todd KH, Paice JA, Lipman AG, Bookbinder M, Sanders SH, Turk DC, Carr DB: American Pain Society recommendations for improving the quality of acute and cancer pain management: American Pain Society Quality of Care Task Force. Arch Intern Med 165: 1574-1580, 2005

13. Gybels JM: Indications for the use of neurosurgical techniques in pain control. In: Bond MR, Charlton JE, Wolf $\mathrm{J}$ (eds), Proceedings of the Sixth World Congress on Pain. Amsterdam: Elsevier, 1995: 475

14. Hyndman OR, Van Epps C: Possibility of differential section of the spinothalamic tract; a clinical and histologic study. Arch Surg 38: 1036-1053, 1939

15. Jemal A, Bray F, Melissa M, Jacques F, Elizabeth W, David F: Global cancer statistics. CA Cancer J Clin 61: 69-90, 2011

16. Jemal A, Center MM, Desantis C, Ward EM: Global patterns of cancer incidence and mortality rates and trends. Cancer Epidemiol Biomarkers Prev 19: 1893-1907, 2010

17. Jemal A, Siegel R, Xu J, Ward E: Cancer statistics, 2010. CA Cancer J Clin 60: 277-300, 2010
18. Kanpolat Y, Caglar S, Akyar S, Temiz C: CT-guided pain procedures for intractable pain in malignancy. Acta Neurochir Suppl 64: 88-91, 1995

19. Kanpolat Y, Cosman E: Special RF electrode system for CTguided pain procedures. Neurosurgery 38: 600-603, 1996

20. Kanpolat Y: Percutaneous cordotomy, tractotomy, and midline myelotomy, minimally invasive stereotactic pain procedures. In: Seminars in Neurosurgery. Stuttgart, New York: Thieme, 2004: 203-219

21. Kanpolat Y: Percutaneous stereotactic pain procedures: percutaneous cordotomy, extralemniscal myelotomy, trigeminal tractotomy-nucleotomy. In: Burchiel K (ed), Surgical Management of Pain. Stuttgart, New York: Thieme, 2002: 745-762

22. Kanpolat Y, Savas A, Ucar T, Torun F: CT-guided percutaneous selective cordotomy for treatment of intractable pain in patients with malignant pleural mesothelioma. Acta Neurochirurgica 144: 595-599, 2002

23. Kanpolat $\mathrm{Y}$, Ugur HC, Ayten $\mathrm{M}$, Elhan AH: Computed tomography-guided percutaneous cordotomy for intractable pain in malignancy-Technical report. Operative Neurosurgery Supplement 1, 64: ONS187-194, 2009

24. Kvale PA, Selecky PA, Prakash UBS: American College of Chest Physicians. Palliative care in lung cancer: ACCP evidencebased clinical practice guidelines. Chest 132: 368-403, 2007

25. Manchikanti L, Singh A: Therapeutic opioids: A ten-year perspective on the complexities and complications of the escalating use, abuse, and nonmedical use of opioids. Pain Physician; Opioid Special Issue 11: 63-88, 2008

26. Mao J: Opioid-induced abnormal pain sensitivity. Curr Pain Headache Rep 10: 67-70, 2006

27. McCaffery M, Ferrell BR, Pasero C: Nurses' personal opinions about patients' pain and their effect on recorded assessments and titration of opioid doses. Pain Manag Nurs 1: 79-87, 2000

28. Miaskowski C, Cleary J, Burney R, Coyne P, Finley R, Foster R: Guideline for the Management of Cancer Pain in Adults and Children. Glenview, IL: American Pain Society 2005:69-84

29. Pargeon KL, Hailey BJ: Barriers to effective cancer pain management: A review of the literature. J Pain Symptom Manage 18: 358-368, 2005

30. Passik SD, Dugan W, McDonald MV, Rosenfeld B, Theobald DE, Edgerton S: Oncologists' recognition of depression in their patients with cancer. J Clin Oncol 16: 1594-1600, 1998

31. Potter VT, Wiseman CE, Dunn SM, Boyle FM: Patient barriers to optimal cancer pain control. Psychooncology 12: 153-160, 2003

32. Ramalingam SS, Owonikoko TK, Khuri FR: Lung cancer: New biological insights and recent therapeutic advances. CA Cancer J Clin 61: 91-112, 2011

33. Raslan AM, Cetas JS, McCartney S, Burchiel KJ: Destructive procedures for control of cancer pain: The case for cordotomy. J Neurosurg 114: 155-170, 2011

34. Schofield P, Ugalde A, Carey M, Mileshkin L, Duffy M, Ball $D$, Aranda S: Lung cancer: Challenges and solutions for supportive care intervention research. Palliat Support Care 6: 281-287, 2008 
35. Sharpe $M$, Strong V, Allen $K$, Rush R, Postma K, Tulloh A, Maguire $P$, House A, Ramirez A, Cull A: Major depression in outpatients attending a regional cancer centre: Screening and unmet treatment needs. Br J Cancer 90: 314-320, 2004

36. Taren JA, Davis R, Crosby EC: Target physiologic corroboration in stereotaxic cervical cordotomy. J Neurosurg 30: 569-584, 1969

37. Ward S, Donovan HS, Owen B, Grosen E, Serlin R: An individualized intervention to overcome patient-related barriers to pain management in women with gynecologic cancers. Res Nurs Health 23: 393-405, 2000
38. Ward SE, Carlson-Dakes K, Hughes SH, Kwekkeboom KL, Donovan HS: The impact on quality of life of patient-related barriers to pain management. Res Nurs Health 21: 405-413, 1998

39. Ward SE, Goldberg N, Miller-McCauley V, Mueller C, Nolan A, Pawlik-Plank D, Robbins A, Stormoen D, Weissman DE: Patient-related barriers to management of cancer pain. Pain 52: 319-324, 1993

40. White JC, Sweet WH: Pain and the Neurosurgeon: A Forty Year Experience. Springfield, IL: Charles C Thomas, 1969: 220-224 